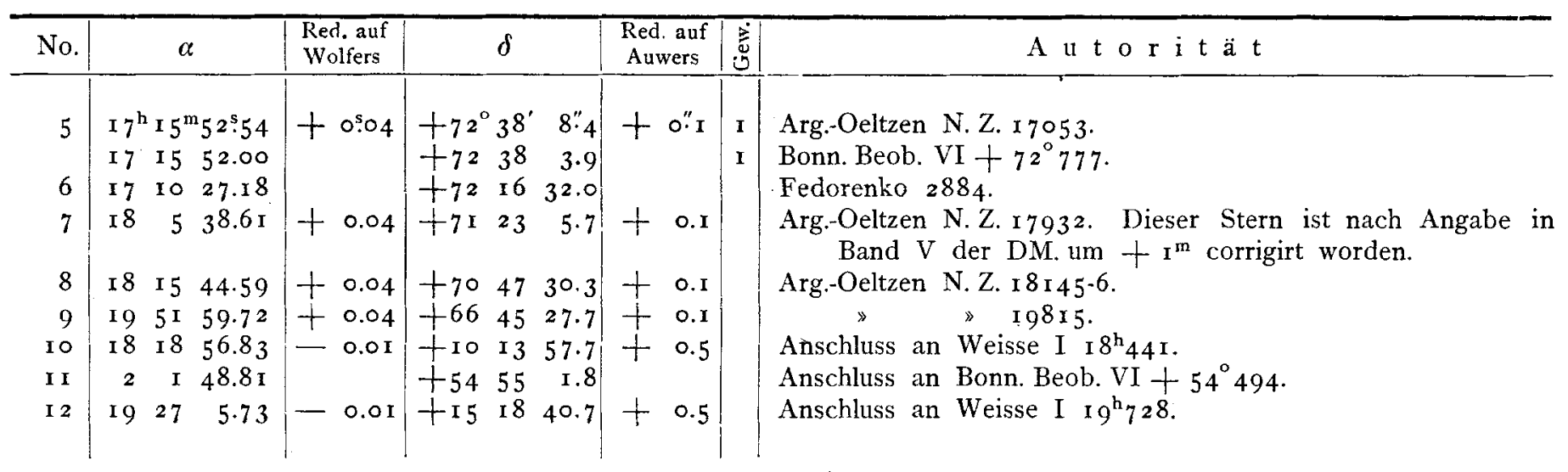

B e $m$ e $r k$ u $n g$ e $n$.

Comet i 88 I III.

188 I Sept. 25. Die geringe Declinationsdifferenz war der Beobachtung hinderlich.

\27. Nebel. of schwach.

Oct. 3. \& schwach. Die Beobachtung wurde durch Wolken unterbrochen.

I I. Dunst. \& sehr schwach.

\ 5 . Sturm. Unruhige Bilder.
I88 $\mathrm{I}$ Nov. 10. $\mathbb{d}^{\prime}$ schwach. Ein $* \mathrm{r} 2^{\mathrm{m}}$ folgte dem of in nächster Nähe.

Die vorstehenden Positionen der Cometen I 880 III, IV, $V$ waren in den Astron. Nachrichten Bd. 99 Nr. 2362 annähernd, nur auf der DM. beruhend, angegeben. Ich habe nachträglich die Vergleichsterne angeschlossen.

Dresden, den 5. December $188 \mathrm{r}$.

B. v. Engelhardt.

\title{
Schreiben von Prof. J. A. C. Oudemans, Director der Sternwarte in Utrecht.
}

Ich sende Ihnen untenstehend einige Meridianbeobachtungen des Cometen I 88 III, welche Herr Amanuensis Verloop auf meine Veranlassung am Repsold'schen UniversalInstrument in dieser Sternwarte angestellt hat, deren Reduction ich aber selbst gemacht habe. Ich beabsichtige hiermit nicht so sehr Material für die Kenntniss des Laufs des Cometen zu liefern, - denn er ist ja an zahlreichen grösseren Meridiankreisen beobachtet worden — sondern einen Beitrag, um zu beurtheilen, ob ein derartiges Instrument auch für Cometen etwas Brauchbares zu liefern im Stande ist. Im Anfange scheint die Declination zu klein beobachtet zu sein, (wie eine. beiläufige Vergleichung mit Greenwich, Warschau und Berlin mir zeigte), welcher Fehler sich aber rasch verminderte. Am Instrument oder an der Ablesung kann dies nicht liegen, also scheint die Einstellung überhaupt an der Seite der Ausströmung stattgefunden zu haben.

\begin{tabular}{|c|c|c|c|c|c|}
\hline I 881 & M. Zt. Utrecht & AR. app.o"' & Decl. app. 65 & $\log p \cdot A$ & Vergleichsterne \\
\hline Juli I I & $13^{\mathrm{h}} 2 \mathrm{I}^{\mathrm{m}_{4}} 48 \mathrm{~s} .03$ & $8^{\mathrm{h}} 42^{\mathrm{m}} 4^{\mathrm{s}} \cdot 3 \mathrm{I}$ & $81^{\circ} 10^{\prime} 22^{\prime \prime} \cdot 2$ & 0.809 & 125 U. C. \\
\hline 12 & 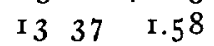 & I $16.9^{2}$ & $\begin{array}{lll}81 & 33 & \text { I } 9.7\end{array}$ & 0.8065 & 4 I I U. C.u. 308 \\
\hline I 3 & $13 \quad 5227.45$ & $\begin{array}{llll}9 & 20 & 41.88\end{array}$ & 815045.0 & 0.804 & 502 u. 42 I U.C. \\
\hline I 4 & 1474 1.83 & $93955.3^{2}$ & $82 \quad 3 \quad 5.4$ & 0.803 & 5 IO 11. 425 U.C. \\
\hline 17 & I 44955.82 & I0 $34 \quad 5.9^{2}$ & 82 I 735.7 & $0.80 \mathrm{I}$ & 433 U. C.u. 529 \\
\hline 18 & I $5 \quad 2 \quad 14.57$ & I0 5023.25 & $82 \times 630.2$ & $0.80 \mathrm{I}$ & 3 I 6 u. 425 U.C. \\
\hline
\end{tabular}

Die Vergleichsterne sind dem Verzeichniss der $\gg 539$ Sterne entnommen. Jeden Abend wurden zwei nördliche Vergleichsterne, der eine in der oberen, der andere in der unteren Culmination beobachtet zur. Bestimmung des Polpunktes, des Azimuthes und der Rectascension. Es wurden auch wohl südliche Sterne für eine Zeitbestimmung beobachtet, diese wurden aber nicht für die AR. des Cometen benutzt. Der Collimationsfehler wurde durch diese in zwei Lagen ausgeführten Zeitbestimmungen bestimmt.

Gang und periodische Ungleichheit der Micrometer- schrauben sind berücksichtigt, auch ist eine Biegung $=4.0 \sin z$, sowohl bei den Vergleichsternen als beim Cometen angewandt. Dieser Coefficient wurde aus einer Polhöhenbestimmung abgeleitet, ausgeführt von Herrn Marine-Lieutenant Blaaur, der sich diesen Sommer an der hiesigen Sternwarte zur Anstellung von geographischen Ortsbestimmungen im ostindischen Archipel, (im Anschluss an die meinigen) vorbereitete. Die Resultate dieser Bestimmung erlaube ich mir hier beizufugen. Die Correction für Biegung ist schon beigefuigt. 


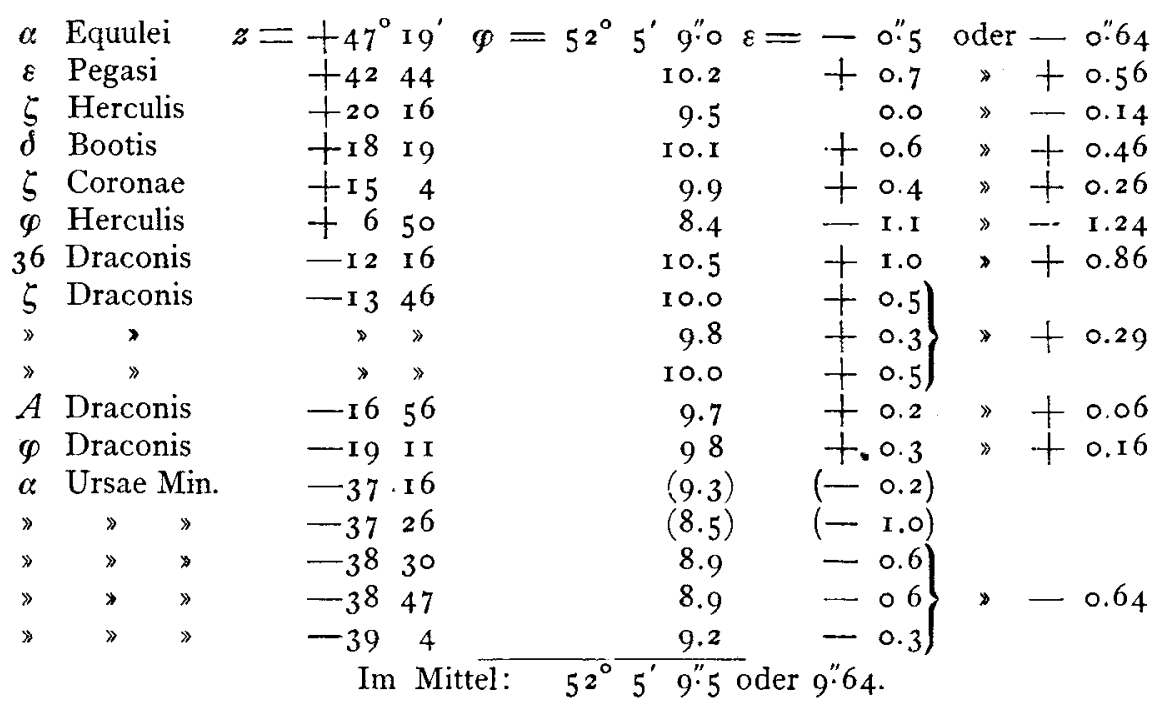

Bei der Bestimmung des Biegungscoefficienten sind den arithmetischen Mitteln zwischen den drei Beobachtungen resp. von $\zeta$ Draconis und $\alpha$ Ursae minoris gleiches Gewicht wie den anderen Bestimmungen zuerkannt. Bei dieser Rechenweise wird die Polhöhe $52^{\circ} 5^{\prime} 9^{\prime \prime} 64$. Die beiden eingeklammerten durch den Polarstern erhaltenen Resultate sind von Herrn Marine-Lieutenant Tadema, und datiren vom Jahre 1878 ; sie stimmen aber sehr gut mit jenen von Herrn Blaaur. Werden diese auch mitgerechnet und die durch denselben Stern erhaltenen getrennt gehalten, so ist das allgemeine Mittel $52^{\circ} 5^{\prime} 9^{\prime \prime} 5$. Sämmtliche Resultate sind Mittel aus 6 oder 8 in abwechselnder Lage ausgeführten Circummeridianbeobachtungen, nur der Polarstern wurde an beliebigen Stellen seines Parallels beobachtet.

Schroeder van der Kolk fand im J. 1857 durch Beobachtungen im ersten Vertical $52^{\circ} 5^{\prime}$ I O." $_{5}$; (A. N. I $28 \mathrm{I}$ ). Von seinen drei Reihen stimmt die dritte aber nicht besonders mit den. beiden ersten (I. Reihe 10". I9; 2. Reihe го."I ; 3. Reihe го" 84). Sein Standpunkt war um o"I9 nördlicher als der Ort des Universal-Instruments. Es bleibt also zwischen der damaligen und der jetzigen Bestimmung noch eine Differenz von 0.8 resp. o.66 übrig, welche wahrscheinlich grösstentheils den Sternörtern zuzuschreiben ist. Leider würde es eine sehr unsichere Sache sein, die Oerter der von Schroeder van der Kolk benutzten Sterne für I 857 auf den Catalog der 539 Sterne zu reduciren, um sein Resultat darnach zu verbessern; und wird es also besser sein, zur Vergleichung der beiden Methoden eine neue Bestimmung im ersten Vertical auszuführen.

Das gebrauchte Universal-Instrument hat einen verticalen Kreis von $260 \mathrm{~mm}$. Durchmesser, (einen horizontalen von $328 \mathrm{~mm}$.), die Oeffnung des Objectivs ist $67 \mathrm{~mm}$., die Vergrösserung war 68. Mit demselben Instrumente habe ich auf dem hiesigen "Dom « eine Azimuthbestimmung von Amersfoort ausgeführt. Von dieser Arbeit wird bald ein Rapport: $\left.{ }^{*}\right)$ nebst Zeichnungen des Instruments erscheinen.

Utrecht I88I November 24 . F. A.C. Oudemans.
$K r$.

\section{Schreiben des Herrn John Tebbutt an den Herausgeber.}

I have read the letter of Dr. Gould dated June $\mathrm{I} 6$ last in Nr. 2384 of the "Astronomische Nachrichten " with much interest. It is quite obvious from the small change in the relative declinations of the comet and the bright star of comparison that the latter could not be a fixed star and the only feasible conclusion is that it was a companion comet. But that this object had no existence a short time previously to Dr. Gould's observation is, I think, shown by negative evidence in the following verbatim extract from my Observatory Journal. The entry is dated Monday, June 13: "The horizon being clear before sunrise yesterday morning, the $\mathrm{I} 2^{\text {th }}$, civil time, I rose to observe the comet. The diffused twilight and the full moon in the opposite part of the sky, however, prevented my seeing any stars near the comet for comparison. There was certainly no star of the 7. mag. or upwards sufficiently near to it. I was, therefore, obliged to make circle comparisons with the bright star Rigel. « Here follow the details of the observations. The method adopted was to observe the transits of Rigel and the comet over the transit thread, while each in its turn was kept bisected by the fixed declination wire, the polar axis being firmly clamped for each comparison. The differences of RA. were inferred from the transits and those of declination from the readings of the declination circle. Four comparisons were made, but in the last the transit time for the comet was not observed, but only the time of bisection. The Windsor mean times of the comet's transit in the first comparison and of its bisection in the fourth were respectively $18^{\mathrm{b}} 22^{\mathrm{m}} 54^{\mathrm{s}} .2$ and $18 \mathrm{~b} 38^{\mathrm{m}} 29^{\mathrm{s}} \mathrm{o}$. On reducing the latter to the meridian of Cordoba it will be found that the observation preceded the first comparison at Cordoba by only $\mathrm{I}^{\mathrm{h}} \mathbf{2}^{\mathrm{m}}$ of absolute 